\title{
Assessment of natural radionuclide levels in attic dust around coal-fired power plant: A case study in city of Salgótarján, Hungary
}

DAVAAKHUU TSERENDORJ ${ }^{1}$, KATALIN ZSUZSANNA SZABÓ $^{2}$, PÉTER VÖLGYESI ${ }^{2}$, GORKHMAZ ABBASZADE ${ }^{1}$, DO LE TAN ${ }^{1}$, NELSON SALAZAR ${ }^{1}$ AND CSABA SZABÓ ${ }^{3}$

${ }^{1}$ Eötvös Lorand University

${ }^{2}$ Centre for Energy Research

${ }^{3}$ Eötvös University

Presenting Author: davaakhuu@student.elte.hu

Primordial radionuclides can be found in all environmental compartments. Coal-fired power plants can be a source of contamination because of coal contains trace amounts of natural radionuclides such as ${ }^{40} \mathrm{~K},{ }^{238} \mathrm{U}$ and ${ }^{232} \mathrm{Th}$ and their decay products. These radionuclides can be released as fly ash from power plant and deposited from atmosphere into ambient environment, subsequently enhancing the natural radioactivity background levels. Thus, undisturbed attic dust preserve signs of long-term pollution, which can be used to examine potential exposure. In city of Salgótarján, a former industrial center in Hungary, the environment was polluted by activity of coal mining, power plant and heavy industry. In this paper, activity measurement of 36 attic dust and a fly-ash slag samples was performed on an area of $98 \mathrm{~km}^{2}$ around the power plant of Salgótarján.

Houses built between 1890 and 1989, considered as representative sampling sites for long-term accumulation. Activity concentrations of ${ }^{238} \mathrm{U},{ }^{232} \mathrm{Th}$ and ${ }^{40} \mathrm{~K}$ in attic dust were determined by low background iron chamber with a well-type HPGe. The mean values of ${ }^{238} \mathrm{U},{ }^{232} \mathrm{Th}$ and ${ }^{40} \mathrm{~K}\left(\mathrm{Bqkg}^{-1}\right)$ in attic dust were found $43 \pm 4,34 \pm 18$ and $534 \pm 27$, respectively, whereas $91 \pm 2,69 \pm 5$ and $414 \pm 9$, respectively, in fly-ash.

The mean activity values were in a good agreement with world mean values for the soil $\left(35,30\right.$ and $\left.400 \mathrm{Bqkg}^{-1}\right)$. Absorbed gamma dose $(\mathrm{nGy} / \mathrm{h})$ and annual effective dose $(\mathrm{mSv} / \mathrm{y})$ rates for attic dust are ranged between 26-161 (mean:75) and 0.1-0.7 (mean:0.3), respectively. In the lack of literature for attic dust data, all values were compared to world average of the indoor absorbed gamma dose rate from terrestrial gamma radiation (75 $\mathrm{nGy} / \mathrm{h})$ and external terrestrial radiation $(0.41 \mathrm{mSv} / \mathrm{y})$. All parameters of dose assessments are within recommended values, except two samples, which are close to power plant. Accordingly, it appears that the fly-ash as a by production of coal-fired power plant does not have a significant impact on the spatial distribution of natural radionuclides in the study area, probably due to its alteration. 